\section{A Rapid Variable-Temperature Micro- or Macro-Dialyser}

PuAPDITY and completeness of dialysis are favoured by a high concentration gradient at the membrane, which, in turn, depends on rapid transport of dialysable material to and from the membrane. At the same time, it is desirable in certain studies to obtain the permeate in the smallest possible volume, to simplify manipulation and to minimize the relative magnitude of analytical blank values. The apparatus is based on these considerations; it is particularly suited for dialysis of suspended materials and can be used at temperatures between 0 and $100^{\circ} \mathrm{C}$. We have employed it in the study of the soluble com. ponents of bacteria (in connexion with work conducted under a research contract (NONR-244(00)) with the Office of Naval Research), the amount of dialysable material varying between $0 \cdot 1$ and $40 \mathrm{mgm}$. of total nitrogen per experiment.

The essential components are a U-tube, a polyethylene-covered magnetic stirring bar, and a horseshoe magnet which is rotated by a small motor. The assembly is shown diagrammatically in Fig. 1. Interaction between the rotating outside magnet (arranged by trial) and the inside magnet moving up-and-down causes rhythmic movements of the casing and agitation of its contents. For larger assemblies the stroke of the inside magnet may be lengthened by putting two magnets end to end (UU) into the clamp. Continuous renewal of the outside fluid is provided by running water slowly through the U-tube. Temperature control is maintained by placing the assembly in a suitable bath. For temperature equilibration the water enters at the bead-filled leg of the tube. The permeate may be sampled or collected in aliquots at the other end. Connexions are made with poly. ethylene tubing which can be used up to $105^{\circ}$. 'Tygon' tubing releases ultra-violet-absorbing substances.

In order to avoid contaminations when dealing with low levels of nitrogen, rubber gloves should be

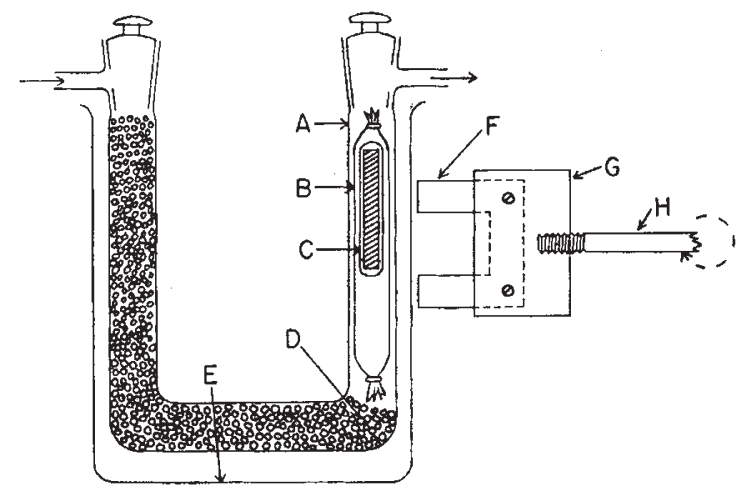

Fig. 1. Dialyser. A, U-tube, the bottom of which can be constricted to prevent beads from shifting into the right arm (absorption tubes, Schwartz, $T$ 12/30 to 24/40 (the legs may be lengthened), No. $J$-310, Scientific Glass, Bloomfleld, N.J.). $B$, dialysis casing knotted on both ends. $C$, stirring bar consisting of $2-6 \mathrm{~cm}$. pieces of rod magnet slipped into polyethylene tubing, the ends being sealed by gentle heat (rod magnets, $\frac{1}{-8}$ in. Alnico grade 2 or 3, magnetized lengthwise, Permag Corp., Brooklyn 5, N.Y., covered with 'Intramedic' polyethylene tubing, wall thickness between 0.3 and $0.6 \mathrm{~mm}$., No. $P E 350$ to $P E$ 440. ClayAdams, New York 10, N.Y.). $D, 4 \mathrm{~mm}$. glass beads. $E$, beaker. $F$, horseshoe magnet (rectangular U-magnet, outside length $1 \frac{3}{4}$ in., inside length electric motor, No. $4 \mathrm{~K} 237$. W. W. Grainger $(24 \mathrm{rev}$. per min. Pa.). The shaft should turn at about 10 rev, per min. The external water space of the U-tube ranged from $15 \mathrm{ml}$. for a $3-\mathrm{ml}$. dialysis casing 'Nojax' casing $8 / 32$ or $18 / 32$ in diameter Visking Corp., Chicago 38 , Ill.) to $100 \mathrm{ml}$, for a $50-\mathrm{ml}$. casing

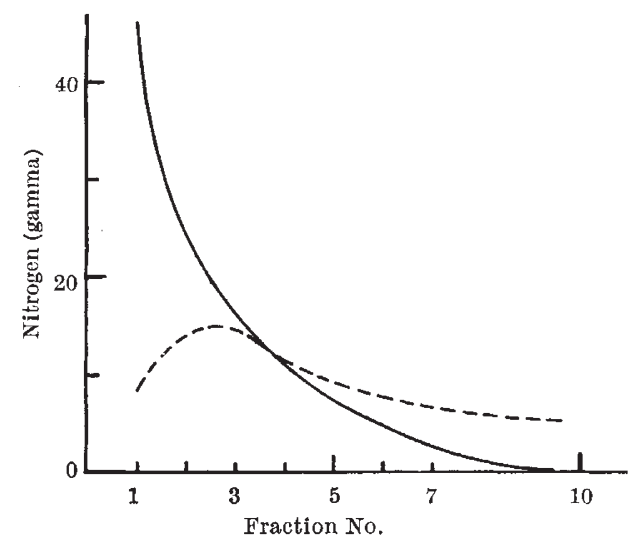

Fig. 2. Effect of agitation. Equal suspensions (43 mgm. dry) of washed lyophilized bacteria were dialysed ( $3 \mathrm{ml}$. inside volume) against water ( 1 ml. per min.) without (dash line) and with (full content of successive $25-\mathrm{ml}$. fractions of the permeate is shown

used for knotting the cellulose casing, and water purified with 'Amberlite $I R-120$ ' for dialysis. 'Nojax' casings show no evidence of mechanical weakening after several hours in boiling water.

Acceleration of dialysis by agitation has been demonstrated ${ }^{1}$. Fig. 2 shows the effect of inside agitation under our experimental conditions. At the time dialysis is complete with inside agitation, the yield is 50 per cent without agitation. Another example may illustrate the practical efficiency of the proposed method : $400 \mathrm{mgm}$. of dry bacterial substance suspended in $5 \mathrm{ml}$. water yielded, in $100 \mathrm{~min}$. of dialysis, during the first $40 \mathrm{~min}$. of which the bath was kept at $100^{\circ}$, a permeate of $100 \mathrm{ml}$. which contained $2 \cdot 24 \mathrm{mgm}$. ninhydrin-nitrogen. Further exhaustive dialysis $(250 \mathrm{ml}$.) yielded an additional $0.07 \mathrm{mgm}$.

Lankenau Hospital Research Institute

H. Stegemann*

G. TOENNIES

and

Institute for Cancer Research.

Philadelphia 11. Pa.

Nov. 3.

* Present address : Medizinische Forschungsanstalt der Max-PlanckGesellschaft, Göttingen.

${ }^{1}$ Kunitz, M., and Simms, H. S., J. Gen. Physiol., 11, 641 (1928).

\section{Quotation of Titles of Papers in Review Articles}

I wIsH to support Dr. Charity Waymouth's plea for the inclusion of titles of papers in the bibliography of a review article.

The editors of "Advances in Virus Research" asked me for a review. I looked at volume 1, the only one then published, and found a very pleasing chaos in the manner of citing references and some authors gave titles in full. I had half written my review when I realized that dull conformity had descended on the journal and that, worse still, it took the form of eliminating titles. To withdraw the article would have meant wasting the time already spent on it so I simply protested, and I welcome the opportunity of protesting again.

Rothamsted Experimental Station, N. W. PIRIE Harpenden, Herts. 